\title{
OPEN The Study of Cotton Extraction by Using Microwave Assisted
}

\author{
Fataa Kusumattaqiin $^{a^{*}}$, Fitriyana $^{a}$, Abdul Halim $^{b}$, Andi Mismawati $^{c}$
}

Abstract. This work aimed to learn the effect of concentration, temperature, and time of extraction toward physical appearances and also changes in lattice parameters. The failed extraction was exhibited by black, transparent, and undissolved cotton. Meanwhile, successful products were indicated by the white suspension. This research was carried out by using the microwave-assisted machine to extract the cotton. The optimum conditions were reached at $55 \%$ acid concentration, $30^{\circ} \mathrm{C}$ reaction temperature, varied time reaction from 1 to 15 minutes. The refinement by using Rietica's software and Le Bail's method showed that the extraction product in a monoclinic crystal structure. It was found the compatibility between experimental data and calculation results. The refinement

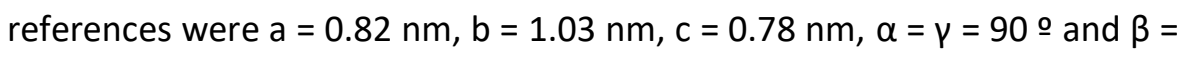
84. Lattice parameter after hydrolysis was greatly different with cotton, mainly in $a$.

Keywords : Cotton, extraction, Lattice Parameter, Le Bail's Method, refinement

${ }^{a}$ Department of Chemical Engineering, Politeknik Negeri Samarinda, East-Kalimantan 75242, Indonesia.

${ }^{\mathrm{b}}$ Department of Mechanical Engineering, Politeknik Negeri Samarinda, East-Kalimantan 75242, Indonesia.

${ }^{c}$ Department of Fisheries Product Technology, Mulawarman University, East-Kalimantan 75119, Indonesia.

Correspondence and requests for materials should be addressed to Kusumattaqiin, F.

(email : fataakusumattaqiin@polnes.ac.id) 


\section{Introduction}

Cellulose is the large material can be found on earth and used in diverse industries [1] -[3]. It can be obtained from several sources such as plants [4]-[6], some sea organism [7] and several bacteria [8][9]. With all the advantages such as reproducibility, degradability, biocompability, it has pulled attention to develop this material in some fields [10]-[12]. Diverse usage of cellulose has already applied in electronic device [13], food packaging [3][14], medicine [15][16], etc.

Cotton, one of the fiber, is commonly used as cosmetics, bedding material, mattress, and used in various textile industry fabric. As modern products, commonly it is blended with the other fiber to provide good performance. According to textile fabric and their selection, cotton has several properties [17] such as; cotton is easy to absorb water (up to 27 times from its weight), cotton is easily attacked by fungi and bacteria especially on wet and warm condition, cotton has excellent properties such as easy to be cleaned, comfort to be used and cheap and cotton fiber as fabric raw material, it has excellent properties. In hot weather, when body perspires, cotton fiber absorbs liquid from our body and is evaporated. In cold weather, when fabric still dry, it keeps body heat.

Based on their specimen, cotton has several types which are Gossypium hirsutum, it is commonly well known as upland cotton or Mexican cotton, Gossypium barbadense, it is commonly well known as extra long staple (ELS) cotton. It generally has a staple of at least $13 / 8$ " or longer, Gossypium arboreum, in another term is well known as tree cotton. It is native species of India, Pakistan, tropical and subtropical region, Gossypium herbaceum, it is commonly well known as Levant cotton. It is native species of semi-arid region regions of sub-Saharan Africa and Arabia [18].

Cotton has higher degree of polymeriza- tion and degree of crystallinity, as compared to other cellulosic fiber. As seen in Table 1, its are as high as $9000-15.000$ and $70 \%$, respectively which are the highest among cotton, rayon and wood pulp. Higher degree of polymerization and crystallinity are associated with high fiber strength. This makes cotton be a promising source of producing biopolymers [18].

Table 1 shows the different between degree polymerization and degree of crystallinity among cotton, rayon and wood pulp. Higher degree of polymerization and crystallinity are associated with high fiber strength.

Microwave assisted extraction is advanced technique to take certain substances from plant material. Conventional technique such as maceration, percolation and decoction are time and solvent consuming. Microwave assisted extraction technique can produce high extraction yield, and decrease time and solvent consumption [20].

Microwave machine is based on a principle of energy absorption of sample and solvent causing vibration/motion on molecule scale, and producing heat. This condition increases the mass transfer rate of the solutes from sample matrix to solvent. By using this machine, the extraction process occurs in controlled environment (pressure, time, temperature and power).

Microwave consists of thermo-well and fiber optic temperature sensor. The thermo-well is a glass tube. A glass tube has one hole with one side closed end. The fiber optic temperature sensor is entered to glass tube. The closed end of the thermo -well is sunk in the sample mixture. The glass tube to cover fiber optic sensor from extreme condition in a vessel. The temperature sensor can read up to $300{ }^{\circ} \mathrm{C}$ and completely inert to all corrosive reagents.

Pressure in vessels can be controlled up to 1500 psi. There are two main parts in pressure sensor. Those are (1) the sensor connecting a vessel pass through a flexible microwave transparent tube

Table 1. Degree of polymerization and crystallinity of cellulose fiber [19]

\begin{tabular}{ccc}
\hline Fiber & Average Degree of Polymerization & Average Crystallinity (\%) \\
\hline Cotton & $9,000-15,000$ & 73 \\
Viscose rayon regular & $250-450$ & 60 \\
Wood pulp & $600-1,500$ & 35 \\
\hline
\end{tabular}




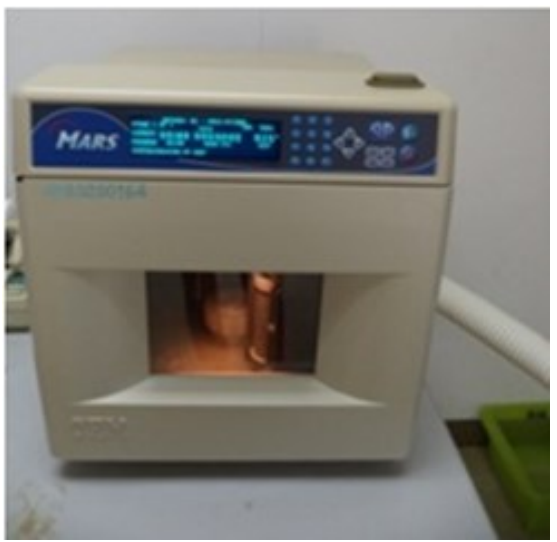

Figure 1. Microwave accelerated reaction system machine [20]

(the blue tubing in Figure 2), and (2) connector and electronic control. A pressure sensing loadcell placed in a black cylinder. Actual pressure in vessels is detected by the load cell, and the load cell delivers a signal to the electronic control unit.

\section{Experimental}

Preparation of Sulfuric Acid and Sodium Hydroxide. Sulfuric acid $35.0 \%(\mathrm{w} / \mathrm{w})$ was prepared by pipetting $35.7 \mathrm{~mL}$ of concentrated sulfuric acid, pouring into $50 \mathrm{~mL}$ of distilled water containing in a $100 \mathrm{~mL}$ volumetric flask and then diluting the solution to $100 \mathrm{~mL}$. The same procedure were performed. Instead, $45.9 \mathrm{~mL}, 56.1 \mathrm{~mL}$ and $66.3 \mathrm{~mL}$ of concentrated $\mathrm{H}_{2} \mathrm{SO}_{4}$ were pippeted in order to prepare $45.0 \%(\mathrm{w} / \mathrm{w}), 55.0 \%(\mathrm{w} / \mathrm{w})$ and $65.0 \%(\mathrm{w} / \mathrm{w})$ respectively. $1 \%(\mathrm{w} / \mathrm{v})$ sodium hydroxide was prepared by weighting $10 \mathrm{mg}$ of sodium hydroxide and diluted with water until $1000 \mathrm{~mL}$.

\section{Result and Discussion}

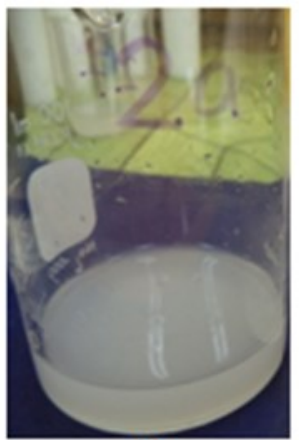

(a)

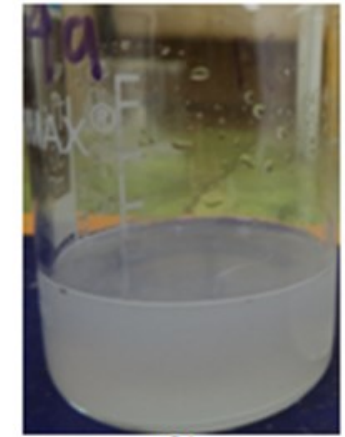

(b)

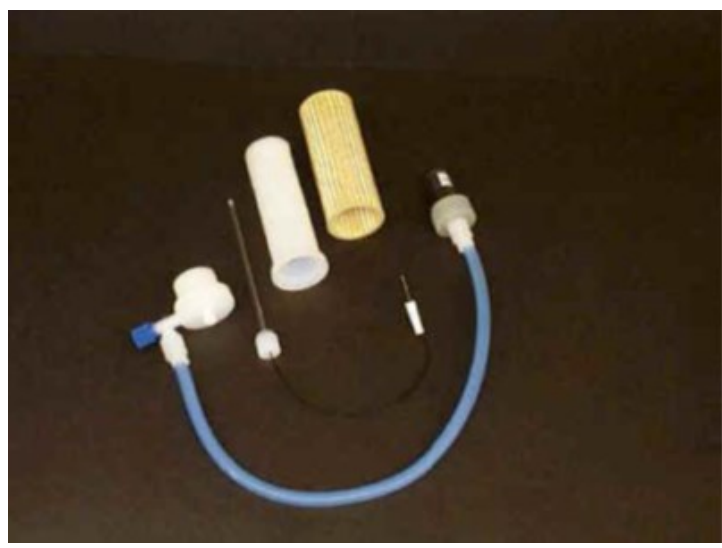

Figure 2. Pressure sensor, temperature sensor, vessel and sleeve (left to right) [20]

\section{The Extraction of Cotton.}

Effect of Acid Concentration. The cotton was extracted from $45.0 \%(\mathrm{w} / \mathrm{w})$ to $65.0 \%(\mathrm{w} / \mathrm{w})$ of sulfuric acid concentration. When the acid concentration further increased to $65.0 \%(\mathrm{w} / \mathrm{w})$, the suspension turned black. This result suggested that the decomposition of cotton formed under this condition [21]. Thereby, $\mathrm{H}_{2} \mathrm{SO}_{4}$ concentration of $55.0 \%$ $(\mathrm{w} / \mathrm{w})$ was adopted in the optimization of the preparation.

Xiang et al [22] suggested that the early step of cellulose hydrolysis involves diffusion of sulfuric acid to cellulose matrix. A proper concentration of sulfuric acid to diffuse into cellulose matrix was important to hydrolyze a material.

Effect of Reaction Temperature. The temperature controlled by the auto-adjusting microwave was set at $30^{\circ} \mathrm{C}, 40^{\circ} \mathrm{C}$ and $50^{\circ} \mathrm{C}$, respectively. The maximum concentration of $55.0 \%(\mathrm{w} / \mathrm{w})$ and reaction time of 2 minutes were used. The suspension became black at a reaction temperature of $50^{\circ} \mathrm{C}$. At this temperature, the hydrolysis reaction of cotton was so high that the crystalline region was broken.

Effect of Reaction Time. The maximum re-

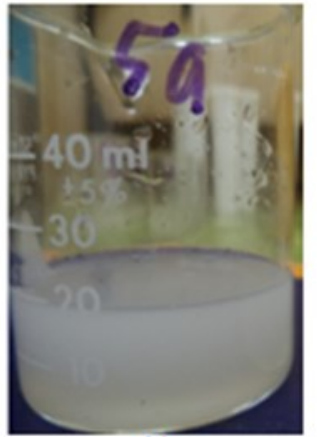

(c)

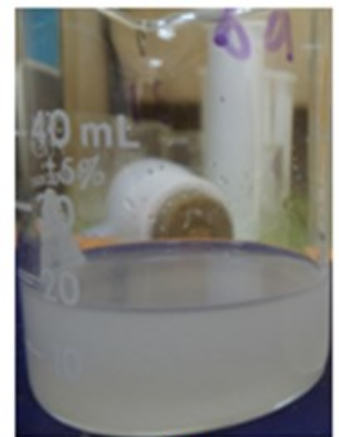

(d)

Figure 3 Extracted samples at optimum conditions, $55.0 \%(\mathrm{w} / \mathrm{w}), 30^{\circ} \mathrm{C}$, with difference in time (a) $1 \mathrm{mi}-$ nute (b) 5 minutes (c) 10 minutes and (d) 15 minutes 


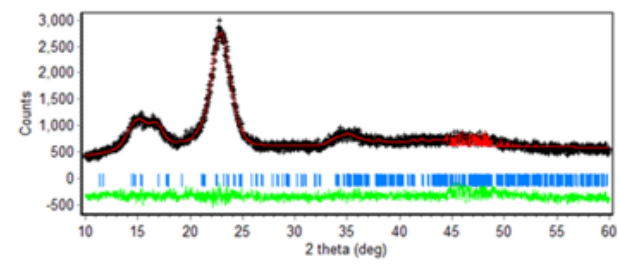

(a)

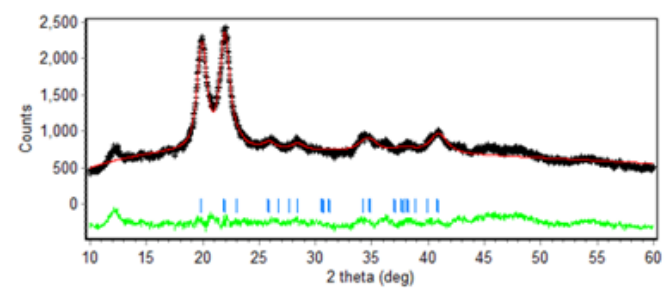

(c)

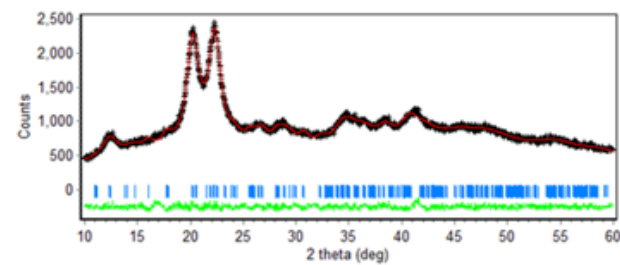

(b)

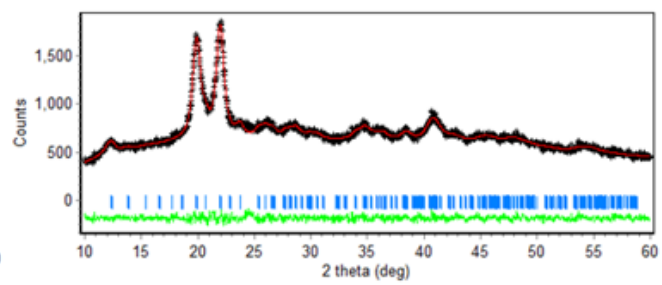

(d)

Figure 4. XRD refinement of (a) cotton (b) acid concentration observation (c) reaction temperature observation and (d) reaction time observation by using Rietica software, Le Bail method. Symbol of (+) represents data observation of XRD, red line represents calculation results, vertical blue line represents expected Bragg position and green line represents the difference between observation and calculation data.

action temperature of $30^{\circ} \mathrm{C}$ and concentration of $55.0 \%(\mathrm{w} / \mathrm{w})$ were used as further experiment. Reaction time was varied from 1 minute to 15 minutes. This experiment at all time reaction showed white suspension which indicated the cotton extraction was successfully obtained.

Refinement. To determine the lattice parameters of cotton wool and MCCs, the XRD refinements were carried out using Rietica software with a Le Bail method. Le bail method extracts data from experimental sources such as intensity $\left(I_{\mathrm{hk}}\right)$. This method can be used to estimate atomic structure of a crystalline material. The advantages of this method like checking purity of the materials.

By using Le Bail method, the unit cell and the approximate space group of the sample must be predetermined because they are included as a part of the fitting technique. The algorithm involves refining the unit cell, profile parameters, and peak intensities to match the measured diffraction pattern.

In this work, cell parameters of cellulose reported by Buyukakinci [23] were used as references for refinement process where $a=0.82 \mathrm{~nm}, b=$ $1.03 \mathrm{~nm}, c=0.78 \mathrm{~nm}, \alpha=\gamma=90 \cong$ and $\beta=84$. Figure 4 shows the XRD fitting process for samples. It was found that the compatibility between the measured diffraction pattern and the fitting pattern was exhibited for all samples. The lattice parameters of cotton wool and MCC samples obtained from each refinement are shown in Table 2.

In Table 2, the lattice parameters proved that the crystal structure of cotton is monoclinic $\left(I_{\beta}\right)$. The results also agreed with that reported by Park et al [24] that cellulosic plants had a monoclinic $\left(I_{\beta}\right)$ crystalline structure. Changes in lattice parameters was found after hydrolysis, especially $a$. The $a$ parameter of cotton extraction was slightly lower than that of cotton wool.

Table 2. The lattice parameters of cotton wool and samples obtained from XRD refinement

\begin{tabular}{lcccc}
\hline \multirow{2}{*}{ Lattice Parameter } & \multicolumn{4}{c}{ Sample } \\
\cline { 2 - 5 } & Cotton & Extraction 1 & Extraction 2 & Extraction 3 \\
\hline Crystal System & Monoclinic & Monoclinic & Monoclinic & Monoclinic \\
$a(\AA)$ & 8.04480 & 7.21390 & 6.39250 & 6.96430 \\
$b(\AA)$ & 10.0587 & 9.74320 & 8.26530 & 10.11810 \\
$c(\AA)$ & 7.79890 & 7.32980 & 6.96200 & 7.88590 \\
$\beta\left({ }^{\circ}\right)$ & 84.05890 & 85.36840 & 87.82680 & 87.13850 \\
\hline
\end{tabular}




\section{CONCLUSION}

In this research, cotton was extracted by microwave assisted and sulfuric acid as hydrolysis agent. The optimum conditions were reached at $55 \%$ of sulfuric acid (the effect of concentration), $30^{\circ} \mathrm{C}$ (the effect of temperature) and in all reaction time (the effect of reaction time). In addition, the refinement of XRD data using Rietica software with Le Bail method indicated that the crystal structure of extraction product were in the monoclinic system.

\section{References}

[1] Cui, S., Zhang, S., Ge, S., Xiong, L. \& Sun, Q. Green preparation and characterization of size-controlled nanocrystalline cellulose via ultrasonic-assisted enzymatic hydrolysis. Ind. Crops Prod. 83. 346-352. (2016). DOI: 10.1016/i.indcrop.2016.01.019.

[2] Bettaieb, F., Khiari, R., Dufresne, A., Mhenni, M. F., Putaux, J. L., \& Boufi, S. Nanofibrillar cellulose from Posidonia oceanica: Properties and morphological features. Ind. Crops Prod. 72. 97-106. (2015). DOI: 10.1016/j.indcrop.2014.12.060.

[3] Zarnuji, A., Amrulloh, H., \& Azizah, I. N. Utilization of Rice Husk Waste for Paper Raw Materials as An Arabic Calligraphy Media. Engagem. J. Pengabdi. Kpd. Masy. 3 (1). 43 -54. (2019). DOI: $\underline{10.29062 /}$ engagement.v3i1.49.

[4] Xiong, R., Lu, C., Wang, Y., Zhou, Z., \& Zhang, X. Nanofibrillated cellulose as the support and reductant for the facile synthesis of $\mathrm{Fe}_{3} \mathrm{O}_{4} / \mathrm{Ag}$ nanocomposites with catalytic and antibacterial activity. J. Mater. Chem. A. 1 (47). 14910-14918. (2013). DOI: 10.1039/c3ta13314a.

[5] Habibi, Y., Goffin, A. L., Schiltz, N., Duquesne, E., Dubois, P., \& Dufresne, A. Bionanocomposites based on poly ( $\varepsilon$-caprolactone)grafted cellulose nanocrystals by ringopening polymerization. J. Mater. Chem. 18 (41). 5002-5010. (2008). DOI: 10.1039/ b809212e.

[6] Kurniawan, Y. S., Priyangga, K. T. A., Krisbiantoro, P. A., \& Imawan, A. C. Green Chemistry Influences in Organic Synthesis: a Review. J. Multidiscip. Appl. Nat. Sci. 1 (1). 1-12. (2021). DOI: 10.47352/imans.v1i1.2.

[7] Bettaieb, F., Khiari, R., Dufresne, A., Mhen- ni, M. F., \& Belgacem, M. N. Mechanical and thermal properties of Posidonia oceanica cellulose nanocrystal reinforced polymer. Carbohydr. Polym. 123. 99-104. (2015). DOI: 10.1016/i.carbpol.2015.01.026.

[8] Roman, M. \& Winter, W. T. Effect of Sulfate Groups from Sulfuric Acid Hydrolysis on the Thermal Degradation Behavior of Bacterial Cellulose. Biomacromolecules. 5. 1671-1677. (2004).

[9] Liang, H. W., Guan, Q., Zhu, Z. Z., Song, L. T., Yao, H. B., Lei, X., Yu, S. H. Highly conductive and stretchable conductors fabricated from bacterial cellulose. NPG Asia Mater. 4 (6). (2012). DOI: 10.1038/am.2012.34.

[10] Shen, X., Shamshina, J. L., Berton, P., Gurau, G., \& Rogers, R. D. Hydrogels based on cellulose and chitin: Fabrication, properties, and applications. Green Chem. 18 (1). 53-75. (2015). DOI: $10.1039 / \mathrm{c5}$ gc02396c.

[11] Liu, J., Willför, S., \& Xu, C. A review of bioactive plant polysaccharides: Biological activities, functionalization, and biomedical applications. Bioact. Carbohydrates Diet. Fibre. 5 (1). 31-61. (2015). DOI: 10.1016/i.bcdf.2014.12.001.

[12] Moon, R. J., Martini, A., Nairn, J., Simonsen, J., \& Youngblood, J. Cellulose nanomaterials review: Structure, properties and nanocomposites. Chem. Soc. Rev. 40 (7). 3941-3994. (2011). DOI: $10.1039 / \mathrm{c0cs00108b}$.

[13] Razaq, A., Khan, A. A., Shakir, U., \& Arshad, A. Next Generation Flexible Antennas for Radio Frequency Applications. Trans. Electr. Electron. Mater. 19 (5). 311-318. (2018). DOI: $10.1007 /$ s42341-018-0051-7.

[14] Arrieta, M. P., Samper, M. D., Aldas, M., \& López, J. On the use of PLA-PHB blends for sustainable food packaging applications. $\mathrm{Ma}$ terials (Basel). 10 (9). (2017). DOI: 10.3390/ ma10091008.

[15] Sehaqui, H., Morimune, S., Nishino, T., \& Berglund, L. A. Stretchable and strong cellulose nanopaper structures based on polymercoated nanofiber networks: An alternative to nonwoven porous membranes from electrospinning. Biomacromolecules. 13 (11). 36613667. (2012). DOI: $10.1021 / \mathrm{bm} 301105 \mathrm{~s}$.

[16] Amrulloh, H., Fatiqin, A., Simanjuntak, W., Afriyani, H., \& Annissa, A. Antioxidant and Antibacterial Activities of Magnesium Oxide Nanoparticles Prepared using Aqueous Extract of Moringa Oleifera Bark as Green Agents. J. Multidiscip. Appl. Nat. Sci. 1 (1). 44-53. (2021). 
DOI: 10.47352/jmans.v1i1.9.

[17] Li, P., Wang, B., Xu, Y. J., Jiang, Z., Dong, C., Liu, Y., \& Zhu, P. Ecofriendly FlameRetardant Cotton Fabrics: Preparation, Flame Retardancy, Thermal Degradation Properties, and Mechanism. ACS Sustain. Chem. Eng. 7 (23). 19246-19256. (2019). DOI: 10.1021/acssuschemeng.9b05523.

[18] Nicolaï, A., Sumpter, B. G., \& Meunier, V. Tunable water desalination across graphene oxide framework membranes. Phys. Chem. Chem. Phys. 16 (18). 8646-8654. (2014). DOI: 10.1039/c4cp01051e.

[19] Kruer-Zerhusen, N., Cantero-Tubilla, B., \& Wilson, D. B. Characterization of cellulose crystallinity after enzymatic treatment using Fourier transform infrared spectroscopy (FTIR). Cellulose. 25 (1). 37-48. (2018). DOI: 10.1007/s10570-017-1542-0.

[20] Singh, S., Gaikwad, K. K., Il Park, S., \& Lee, Y. $\mathrm{S}$. Microwave-assisted step reduced extraction of seaweed (Gelidiella aceroso) cellulose nanocrystals. Int. J. Biol. Macromol. 99. 506-510. (2017). DOI: $10.1016 /$ j.ijbiomac. 2017.03.004.

[21] Lu, Z., Fan, L., Zheng, H., Lu, Q., Liao, Y., \& Huang, B. Preparation, characterization and optimization of nanocellulose whiskers by simultaneously ultrasonic wave and microwave assisted. Bioresour. Technol. 146. 8288. (2013). DOI: 10.1016/ j.biortech.2013.07.047.

[22] Xiang, Q., Lee, Y. Y., Pettersson, P. O., \& Torget, R. W. Heterogeneous Aspects of Acid Hydrolysis of $\alpha$-Cellulose. Biotechnol. Fuels Chem. 505-514. (2003). DOI: 10.1007/978-1-4612-0057-4 42.

[23] Büyükakinci, B. Y. Investigation of the internal structure of regenerated bamboo fiber. Tekst. ve Konfeksiyon. 20 (4). 277-283. (2010).

[24] Park, S., Baker, J. O., Himmel, M. E., Parilla, P. A., \& Johnson, D. K. Cellulose crystallinity index: Measurement techniques and their impact on interpreting cellulase performance. Biotechnol. Biofuels. 3. (2010). DOI: 10.1186/1754-6834-3-10. 